\title{
Effects of Mowing Regimes on the Growth and Vegetation Dynamics of Established White Clover (Trifolium repens $\mathrm{L}_{\text {.) }}$ Cover for Weed Suppression*
}

\author{
Motoaki Asai**, Misako Ito** and Tokuichi Kusanagi**
}

\begin{abstract}
To determine the optimal mowing regime for the maintenance of two cultivars (Grasslands Huia and California Ladino) of white clover sod and its weed suppression, field trials were conducted for two years beginning in 1991. Sixteen mowing regimes were evaluated: all combinations of frequency and time of mowing 4 times a year, spring (mid April or early May), June, August and October. During the first year, mowing regimes little affected clover growth and the vegetation dynamics, but in the second year they significantly affected them. Clover coverage declined in the summer of 1993 because of the depression of clover growth and weed invasion caused by creation of a gap after mowing. June mowing, in particular, induced emergence of large summer grasses, e.g., Setaria faberi and Digitaria ciliaris, which suppressed clover. Mowing in August and October increased emergence of winter annuals, while June mowing increased that of summer annual weeds. The winter annuals were not noxious, but some summer grasses had adverse effects on clover. Regardless of mowing, Rumex spp. and Lolium multiflorum increased their dominance ratio in all the treat-

* An earlier version of this paper was presented at the 33rd Annual Meeting of the Weed Science Society of Japan (1994).

** Weed Science Laboratory, Faculty of Agriculture, Kyoto University, Kyoto 606-01, Japan.

(Received April 10, 1995)
\end{abstract}

ments. 'Ladino' exhibited more continuous dense cover and superior weed suppression than 'Common'. Mowing at other than 'spring flush' stage should be avoided to maintain established clover sod.

Key words: Trifolium repens L., mowing regime, vegetation dynamics, sod cover, weed suppression

\section{Introduction}

Covering ground with less noxious and labor-saving maintainable herbaceous plants is a useful option where plant cover is necessary but noxious species should be eliminated, such as orchard floors and amenity grasslands. We viewed white clover (Trifolium repens L.) as a species possibly capable of serving for this purpose, and showed that its stand is more time-saving for mowing than other grass weeds ${ }^{3}$. We then conducted a study to find an adequate method to establish and maintain good clover sods.

Effects of seeding time and rate on clover establishment and its weed suppression were reported earlier ${ }^{2}$. In this paper, effects of mowing regimes differing in frequency and time during the season on the maintenance of established clover sods are described.

\section{Materials and Methods}

An experiment was carried out from September 1991 to December 1993 at the Experi- 
mental Farm of Kyoto University, Takatsuki City, Osaka, Japan. Details of the experimental plots and general procedures were described in the previous paper ${ }^{2)}$. Two clover cultivars, Grasslands Huia (Common type) and California Ladino (Ladino type), abbreviated 'Common' and 'Ladino' hereafter, were compared. Clovers were seeded on 18 September or 14 October 1991, at 2.0 $\mathrm{kg} / 10 \mathrm{a}$ or $0.5 \mathrm{~kg} / 10 \mathrm{a}$. They had successfully established by the following spring regardless of the seeding method. Vegetation measurements were the same as those reported ${ }^{2}$. To evaluate the effects of mowing regimes, the means of all data were averaged over seeding times and seeding rates.

\section{Mowing treatment}

We carried out sixteen mowing regimes, using all combinations of frequency and time of mowing at 4 different times a year, Spring (mid April to early May), June, August and October in 1992 and 1993. Mowing dates and their combinations are shown in Table 1. Each stand was uniformly mown to about 5 $\mathrm{cm}$ above the soil surface, only to cut clover petioles, but not to damage the stolons. Mown plant debris was left on each plot, covering the soil surface.

Multivariate analysis of variance was used to determine the significant differences in clover's multiplied dominance ratio $\left(\mathrm{MDR}_{2}\right.$, the product of clover coverage rank and plant height) between mown and not-mown treatments.

\section{Weed-free treatment}

To evaluate the effects of weeds on clover growth during the summer, 16 blocks were given a weed-free treatment (two cultivars by eight replications). All the weeds in the blocks were removed by hand to maintain pure clover stands for the three months from 8 July to 20 October. Mann-Whitney U test was used to determine the significant
Table 1. Time schedule of mowing treatments.

\begin{tabular}{|c|c|c|c|c|c|c|}
\hline \multirow[b]{2}{*}{ Plot } & \multicolumn{6}{|c|}{ Mowing frequency } \\
\hline & $\begin{array}{l}1992 \\
1993\end{array}$ & $\begin{array}{l}\text { Spring } \\
\text { 17, Apr. } \\
\text { 1, May }\end{array}$ & $\begin{array}{c}\text { June } \\
19 \\
14\end{array}$ & $\begin{array}{c}\text { Aug. } \\
7 \\
25\end{array}$ & $\begin{array}{c}\text { Oct. } \\
19,20 \\
15\end{array}$ & Total/year \\
\hline 1 & & 1 & 1 & 1 & 1 & 4 \\
\hline 2 & & 1 & 1 & 1 & 0 & 3 \\
\hline 3 & & 1 & 1 & 0 & 1 & 3 \\
\hline 4 & & 1 & 1 & 0 & 0 & 2 \\
\hline 5 & & 1 & 0 & 1 & 1 & 3 \\
\hline 6 & & 1 & 0 & 1 & 0 & 2 \\
\hline 7 & & 1 & 0 & 0 & 1 & 2 \\
\hline 8 & & 1 & 0 & 0 & 0 & 1 \\
\hline 9 & & 0 & 1 & 1 & 1 & 3 \\
\hline 10 & & 0 & 1 & 1 & 0 & 2 \\
\hline 11 & & 0 & 1 & 0 & 1 & 2 \\
\hline 12 & & 0 & 1 & 0 & 0 & 1 \\
\hline 13 & & 0 & 0 & 1 & 1 & 2 \\
\hline 14 & & 0 & 0 & 1 & 0 & 1 \\
\hline 15 & & 0 & 0 & 0 & 1 & 1 \\
\hline 16 & & 0 & 0 & 0 & 0 & 0 \\
\hline
\end{tabular}

differences in clover coverage between the weed-free plots and the control.

\section{Results}

\section{Effects of mowing on clover cover}

Clovers coverage was up to $90 \%$ in all the plots before the first mowing and this was maintained for a year (Fig. 1). The coverage decreased to 90 to $60 \%$ during the following winter and then again increased in the next spring (Fig. 1). In the summer of 1993, however, all clovers had declined, regardless of mowing (Fig. 1). 'Ladino' coverage remained higher than 'Common' throughout the latter year of the experiment (Fig. 1).

To evaluate the significance of mowing effects on clover dominance, $F$ value probabilities in the clover $\mathrm{MDR}_{2}$ difference between mown and not-mown treatments were determined (Table 2). Larger value approaching one indicates that the effect of mowing was negligible. Smaller value indicates more significant effect of mowing, in 

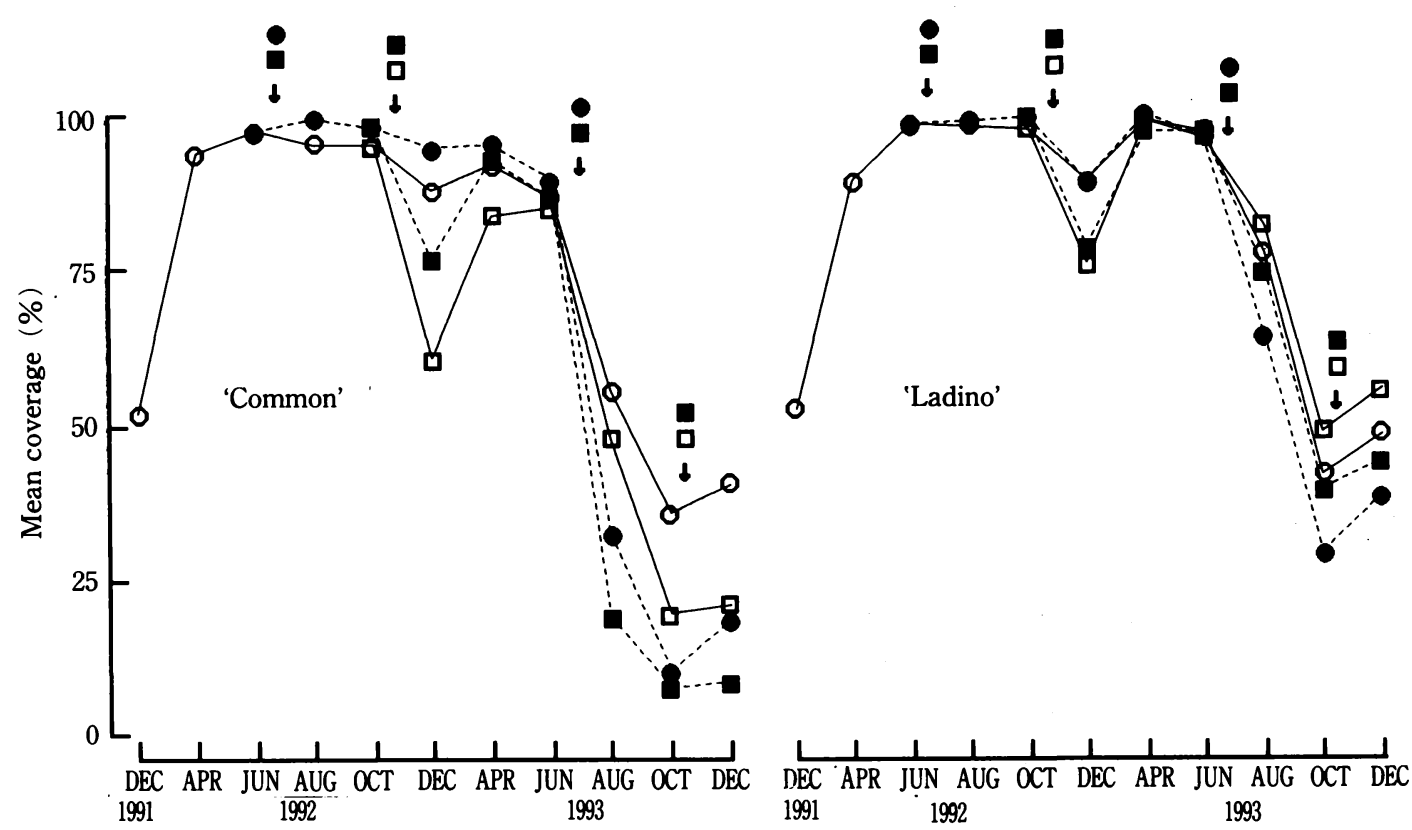

Fig. 1. Changes in mean coverage as affected by June and October mowing. a (घ), June and October. b (๑) June only. c (口) October only. d (O) no mowing. Arrows indicate times of mowing.

most cases, which decreased clover coverage. The smallest values were attained by mowing in October 1992 and June 1993 in both cultivars (Table 2), since both of the mowings severely decreased clover coverage (Fig. 1). The decreasing significance of the October mowing during spring 1993 (Table 2) indicated that the effect had disappeared due to the clover recovery (Fig. 1). Mowing in June 1993 accelerated rapid decline of clover growth thereafter (Fig. 1), while mowing in spring and August in both years was recognized to have little effect on clover dominance (Table 2). Mowing in October 1993 also did not increase clover coverage (Fig. 1) ; thus, in 1993, neither August nor October mowing was able to restore the coverage to its original level. October mowing was more detrimental to 'Common' than to 'Ladino' (Fig. 1).

Significant interactions between different mowing times were detected in 3 combina- tions in 'Ladino', but ' none in 'Common' (Table 2). Interaction between mowing in May and June 1993 appeared significant in autumn, mainly because May mowing itself encouraged clover growth, but successive mowing in May and June slowed it to a standstill. Interaction between mowing in June and August 1993 was also significant in late 1993, primarily because the effect of August mowing following June mowing was different from the case when mowing was not done in June. The effect of August mowing was more adverse in the latter case. Competition between clover and other weed species may have been involved in this trend. Another interaction in April, August and October 1992 was also significant in June 1993, but it did not seem important.

\section{Effects of weed-free treatment on clover} cover

Clover coverage in the weed-free plot decreased from June to August and slightly 
Table 2. Significance of $\mathrm{F}$ tests by ANOVA for four mowing times on clover's multiplied dominance ratio $\left(\mathrm{MDR}_{2}\right)$.

\begin{tabular}{|c|c|c|c|c|c|c|c|c|c|c|}
\hline \multirow{3}{*}{ Cultivar } & \multirow{3}{*}{ Mowing time } & \multicolumn{9}{|c|}{$-F$ value probabilities ${ }^{a}$ - } \\
\hline & & \multicolumn{4}{|c|}{1992} & \multicolumn{5}{|c|}{1993} \\
\hline & & June & Aug. & Oct. & Dec. & Apr. & June & Aug. & Oct. & Dec. \\
\hline \multirow[t]{8}{*}{ 'Common' } & 1992, April & $.045^{*}$ & .923 & .454 & .160 & .395 & - & - & - & - \\
\hline & June & - & .846 & .875 & $.013^{*}$ & $.004^{* *}$ & .519 & - & - & - \\
\hline & August & - & - & .116 & $.046^{*}$ & .257 & .149 & .609 & - & - \\
\hline & October & - & - & - & $<.001^{* * *}$ & $<.001^{* * *}$ & .098 & $.048^{*}$ & $.035^{*}$ & - \\
\hline & 1993, May & - & - & - & - & - & .308 & .478 & .135 & .502 \\
\hline & June & - & - & - & - & - & - & $<.001^{* * *}$ & $<.001^{* * *}$ & $<.001^{* * *}$ \\
\hline & August & - & - & - & - & - & - & - & .789 & .737 \\
\hline & October & - & - & - & - & - & - & - & - & $<.001^{* * *}$ \\
\hline \multirow[t]{8}{*}{ 'Ladino' } & 1992, April & .283 & .375 & .287 & .256 & .670 & - & - & - & - \\
\hline & June & - & .279 & .570 & .576 & .969 & .114 & - & - & - \\
\hline & August & - & - & .329 & .273 & .938 & .075 & .160 & - & - \\
\hline & October & - & - & - & $<.001^{* * *}$ & $.004^{* *}$ & .246 & .356 & .156 & - \\
\hline & 1993, May & - & - & - & - & - & .397 & .817 & .834 & .712 \\
\hline & June & - & - & - & - & - & - & $<.001^{* * *}$ & $<.001^{* * *}$ & $<.001^{* * *}$ \\
\hline & August & - & - & - & - & - & - & - & .810 & .453 \\
\hline & October & - & - & - & - & - & - & - & - & .083 \\
\hline \multicolumn{11}{|c|}{ 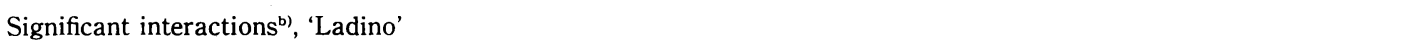 } \\
\hline \multicolumn{2}{|c|}{ Apr. ' $92 \times$ Aug. ' $92 \times$ Oct. ' 92} & - & - & - & .331 & $.046^{*}$ & - & $\longrightarrow$ & - & - \\
\hline \multicolumn{2}{|c|}{ May. '93× June '93 } & - & - & - & - & - & - & .535 & $.005^{* *}$ & $.001^{* *}$ \\
\hline \multicolumn{2}{|c|}{ June ' $93 \times$ Aug. '93 } & - & - & - & - & - & - & - & $.006^{* *}$ & $.013^{*}$ \\
\hline
\end{tabular}

a) ${ }^{*},{ }^{* *}$ and ${ }^{* * *}$ Indicate significance of mowing at $\mathrm{P}<.05, .01, .001$, using ANOVA, respectively.

b) Only significant interactions are listed. No significant interactions were detected in 'Common'.

increased from August to December (Fig. 2). Weed-free treatment reduced the degree of decline in the coverage that was marked in the unweeded control, although the difference was significant only in 'Common' (Fig. 2). These results indicate that the clover depression in the second summer was due not only to the weed infestation but also to low growth ability of clovers.

\section{Effects of mowing on vegetation dynamics}

Mowing in October 1992 and June 1993 also affected the floristic composition of the stands. Gaps created by the October mowing allowed invasion of some winter annual weeds (e.g., Stellaria media (L.) Vill. and Geranium carolinianum L.). In some plots, these winter annuals had dominated during spring, but did not compete with clover as did
Capsella bursa-pastoris (L.) Medik. in the previous year ${ }^{2}$. These weeds were replaced by clover after its spring flush. Few $C$. bursa-pastoris, the sub-dominant species in the previous year, were seen.

Mowing in June 1993 caused drastic population shift in the clover stands. In December 1993, at the end of the experiment, the lowest clover dominance ratio among all the mowing regimes was observed in the plot where clovers were mown in October 1992, May and June 1993 and not mown in August (plot 3, in Table 1). Contrarily, the highest was observed in the plots where only spring or no mowing was conducted (plots 8 and 16). Dominance-diversity curves ${ }^{17}$ for each plot were expressed by plotting the $\log \mathrm{MDR}_{2}$ of the species in the decreasing order of the ranking : those in the lowest and the highest 


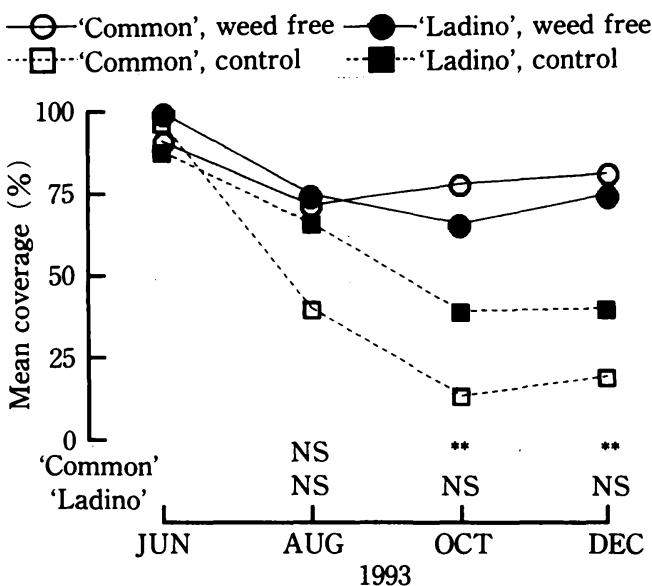

Fig. 2. The effect of weed-free treatment on the mean coverage for two clover cultivars.

Significant differences between treatments within cultivar using Mann-Whitney $U$ test are indicated by asterisks $\left({ }^{* *} P<.01\right.$, NS : no significant).

clover dominance ratio are presented in Fig. 3A (plot 3) and Fig. 3B (plots 8 and 16), respec. tively.

In plot 3 , both cultivars were still dominant in June. However, in 'Common' plots, several summer annual weeds were already ranked by then, in the lower parts of the species sequence (Fig. 3A). These species must have emerged in the gaps created by mowing in October 1992 and May 1993. 'Ladino' plots continued to exhibit almost pure clover stands and summer weeds did not appear until June (Fig. 3A).

Mowing in June created gaps in clover stands, and these gaps then allowed the emergence of summer annual grasses (e.g., Setaria faberi Herrm., Digitaria ciliaris (Retz.) Koeler). In August $S$. faberi became the most dominant in the 'Common' stands (Fig. 3A), shading the 'Common' plants, and its rank in the species sequence was largely degraded. In contrast, 'Ladino' remained second-dominant, following closely the dominant $S$. faberi (Fig. 3A). Once the grass species dominated, their dense stands further
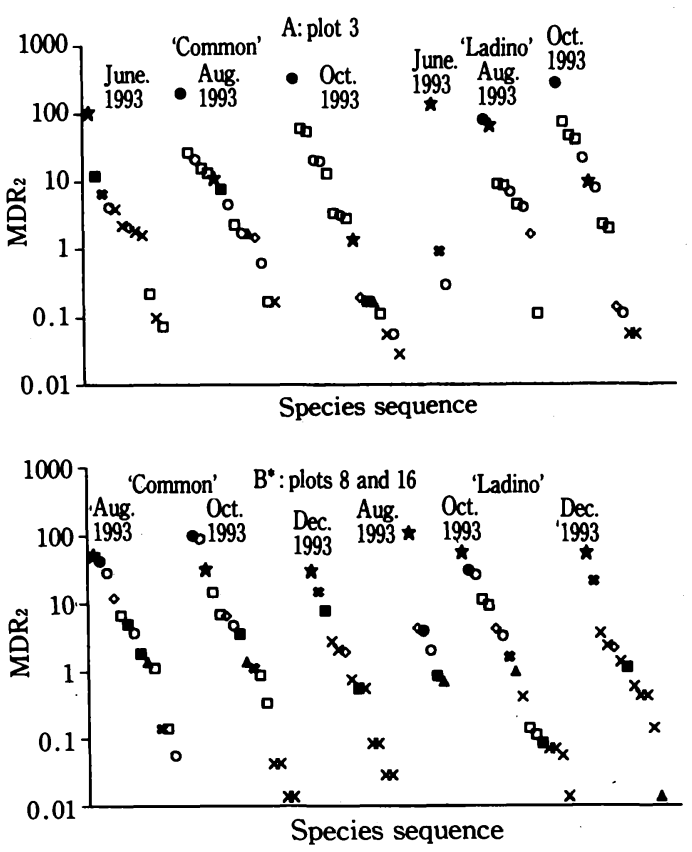

Fig. 3. Changes in dominance-diversity curves for plots under various mowing regimes.

Plot 3 : mown on October, April and June. Plots 8 and 16: mown only in April or without mowing. ${ }^{*}$ Averaged over plots 8 and 16 .

$\star$ : Trifolium repens, $\diamond:$ Rorippa indica, $\boldsymbol{\varkappa}$ : Lolium multiflorum, $\square$ : Rumex spp., ๑: Setaria faberi, $\bigcirc$ : summer annual broad leaf, $\square$ : summer annual grass and sedge, $\times$ : winter annual, $\Delta$ : perennial

suppressed clover in autumn.

In plots 8 and 16 , where clover dominance ratio was highest among the plots, 'Ladino' stands had fewer weed species than 'Common' stands in August (Fig. 3B). Prominent dominance of 'Ladino' continued until October, whereas that of 'Common' was surpassed by summer grass weeds. Although the coverage of both clovers was lower than the previous year (Fig. 1), the two cultivars were dominant in December 1993, followed by Lolium multiflorum Lam., a dominant species in the orchards surrounding the experimental field (Fig. 3B). Dominance of Rumex spp., a typical perennial weed in grassland, was 
Table 3. Effects of mowing on the dominance ratio of weed species in the field.

\begin{tabular}{|c|c|c|c|c|}
\hline \multirow[t]{2}{*}{ Species } & \multicolumn{4}{|c|}{ Time of mowing ${ }^{*}$} \\
\hline & Spring & June & August & October \\
\hline \multicolumn{5}{|l|}{ Rumex conglomeratus } \\
\hline Rorippa indica & $>$ & & $r$ & \\
\hline Erigeron sumatrensis & & $\searrow$ & $\searrow$ & \\
\hline Lolium multiflorum & & $〉$ & $r$ & $r$ \\
\hline Geranium carolinianum & $\searrow$ & & $>$ & $>$ \\
\hline Stellaria media & $>$ & & $>$ & $r$ \\
\hline Poa апnиа & & $\searrow$ & & $r$ \\
\hline Galium spurium & 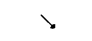 & & $\searrow$ & \\
\hline Setaria faberi & & $>$ & $>$ & \\
\hline S. glauca & & $>$ & $\searrow$ & \\
\hline Digitaria ciliaris & & $r$ & $r$ & \\
\hline Echinochloa crus-galli & & $\nearrow$ & & \\
\hline Commelina communis & $r$ & $r$ & & \\
\hline Acalypha australis & & $>$ & & \\
\hline \multicolumn{5}{|c|}{$\begin{array}{l}*: \text { " } \wedge \text { " and " } \searrow \text { " indicate that dominance ratio } \\
\text { of the species was more enhanced or reduced by } \\
\text { mowing than by no mowing, respectively. No } \\
\text { symbol indicates that the dominance of the } \\
\text { species was not affected by mowing. }\end{array}$} \\
\hline
\end{tabular}

lower in 'Ladino' than in 'Common' (Fig. 3B).

\section{Responses to mowing of major weeds}

Major weed species were differently affected by the four mowings. Their responses evaluated by $\mathrm{MDR}_{2}$ difference between mown and not-mown are summarized in Table 3. Most winter annual weeds increased their dominance ratios in the plots successively mown in August and October more than in the plot without them. In contrast, major summer annual weeds increased their dominance ratios in the plots mown in June than without it. In growth form, $S$. media and $D$. ciliaris, prostrate-branched species, were able to regrow after mowing and continued their reproductive growth. Conversely, Setaria spp., tufted species, were damaged and/or defoliated by mowing in the reproductive growth stage.

In the case without August mowing after June mowing (i.e., plots $3,4,11$ and 12 in
Table 1), $S$. faberi had dominated until autumn. However, after August mowing (i.e., plots 1,2, 9 and 10), D. ciliaris replaced it in dominance. Consequently, as mentioned earlier, clovers were suppressed and their dominance ratio further degraded after August mowing.

Rumex conglomeratus Murr. was not affected by any mowing (Table 3 ), however, its dominance ratio increased in all the plots throughout the experiment (data not shown). L. multiflorum also increased in almost all the plots, especially in the sequential treatment of no June mowing followed by August and October mowing (i.e., plots 5 and 13 in Table 1).

\section{Discussion}

A number of trials have been made on the usage of clovers for orchard sod culture ${ }^{4}$, and a number of surveys were conducted to investigate weed vegetation in orchards in Japan $^{1,7,14)}$. Few of those focused on either clover-weed dynamics or weed suppression with clover cover.

Other studies have been carried out on the effect of mowing frequency and community composition on pasture productivity, especially in grass-legume pasture ${ }^{5}$. With infrequent mowing, 'Ladino' competes with pasture grasses and its vigorous growth reduces total pasture yield ${ }^{6}$. Co existence of Lolium-clover was reported to form an ecologically stable community ${ }^{15}$, and usage of the mixture as forage is common in many temperate regions of the world. In this experiment, maximum mowing frequency was 4 times a year and the shortest mowing interval was 6 weeks. 'Ladino' can yield several times a year and its optimum mowing interval is 30 days $^{12)}$. Shading by tall grasses resulting from longer interval between mowings seems to be more disadvantageous to 
'Common' than to 'Ladino'. Consequently, in most of the mowing regimes, 'Common' coverage decreased more markedly than 'Ladino', and most of the weed species were more obviously suppressed by 'Ladino' than 'Common'. For instance, Solidago altissima L. invaded only in 'Common' stands in late 1993 (data not shown).

Summer growth depression of white clover, a long-day plant, is due to deterioration of the structure for regrowth ${ }^{8,11}$. During the clover flowering stage, the proportion of leaves and petioles to storage organs (stolons and roots) is very high ${ }^{8)}$. This is an advantage for the canopy closure without mowing but not in the following regrowth after mowing $^{8)}$. Our experiment revealed that clover growth was also depressed after June mowing, which induced emergence of competitive summer grasses. Clovers in the weed-free treatment maintained higher coverage than weedy control. Thus, not only high temperature in summer, but inadequate timing of mowing depresses clover growth.

Unusual low temperature and heavy rainfall in summer 1993 were not thought to have caused any adverse effects on clover growth. The experimental site was flooded several times by heavy rainfall in the summer. In a clover-orchardgrass mixture pasture, frequent irrigation in summer was thought to increase the proportion of clover ${ }^{16)}$, and temporal flooding had no detrimental effect on growth of the crop ${ }^{6}$. If low temperature during summer moderates clover depression, the unusual weather of 1993 would seem advantageous to clover survival.

Mowing affected weed emergence and regrowth, and caused a drastic change in vegetation. However, quite a few studies have been made on the effects of mowing regimes on an arable weed community ${ }^{1,13}$. Sugawara ${ }^{13)}$ reported that frequency of mow- ing did not change weed community composition in an upland crop field, although he did not address the season of mowing. Infrequent mowing as conducted in this experiment, however, may be an important factor governing vegetation. Among the weed species appearing, most of the winter weeds did not compete with clover; this finding agrees with that of Nemoto ${ }^{9,10)}$. In contrast, large summer grasses suppressed clover. The established clover stands were greatly changed by mowing, because they had less regrowth ability than in the establishment stage. Mowing in different seasons affected clover vegetation in different ways; mowing in the vigorous clover growth stage had little effect, but mowing when clover was in a declining stage imposed disruption.

Weed response to mowing differed in a specific manner. Mowing disrupts the aboveground part of existing plants and creates gaps which cause seedlings to emerge. Therefore renewal vegetation is dominated by those species with many available propagules, e.g., seed bank, reproductive shoots. Mowing in a later growth stage of dominant species hastens vegetation shift, whereas mowing species with high regrowth ability during their growing season tends to encourage them to dominate. An example of this was reported by $\mathrm{Abe}^{1)}$, August mowing decreased dominance of Setaria and increased that of $D$. ciliaris. Intensive mowing during summer would be required to maintain these grass stands short and sightly. To determine the effect of mowing regimes on weed response and vegetation shift in detail, further investigation is needed, e.g. mowing in July and September.

'Ladino' exhibited more continuous dense cover and superior weed suppression than 'Common'. Thus 'Ladino' seems more suitable as a weed suppressor under extensive 
vegetation management, requiring only infrequent mowing and a minimum of other cultural practices, e.g., cultivation, irrigation, pesticide application and fertilization. The effectiveness of clover, however, can last for a few years.

We came to the following conclusion on the relationship between clover maintenance and mowing. To maintain a good clover sod, mowing only in the spring flush stage (at the peak of clover vegetative growth) or no mowing throughout the season is a promising way in areas where large perennial species are absent. Mowing after the spring flush stage should be avoided, because it forces clover to decline and allows competitive summer weeds to emerge. Once large grass species dominates, clover cover is difficult to recover by mowing alone. Certain large perennial species, e.g., Rumex spp. are hardly controlled by mowing, therefore restricted and spot application of translocating herbicides would be required.

Further trials should be made to extend good clover sod persistence, such as a combination of various clover genotypes: renovation including intertillage and/or overseeding, and phosphate application to enhance clover regrowth.

Finally, it should also be noted that weed response to mowing was specific. Since the weed community includes various species, a certain cultural operation on one species can sometimes induce an opposite result by the responses of other species. Therefore synecology as well as autoecology of major weed species should be integrated as a basis for extensive and labor-saving vegetation control.

Acknowledgments: We appreciate the staffmembers of the Experimental Farm, Kyoto University for their invaluable assis- tance in the field.

\section{References}

1) Abe, K. 1965. Effects of timing of cutting on the vegetation in a sod covered citrus orchard. Agriculture and Horticulture 40(8), 1261-1262. (in Japanese)

2) Asai, M., M. Ito and T. Kusanagi 1995. Effects of seeding methods and mowing on the establishment of white clover (Trifolium repens L.) cover for weed suppression. Weed Res., Japan 40(1), 20-28.

3) Asai, M. and M. Ito 1995. Comparison of mowing efficiencies for stands of clover and several weeds. Weed Res., Japan 40(1), 44-46. (in Japanese)

4) Fujii, H. 1985. Winter-sod culture in citrus orchard. 3. Method of sod management and economic studies on winter-sod culture. Bull. Yamaguchi Agr. Exp. Stn. 37, 139-143. (in Japanese)

5) Haynes, R.J. 1980. Competitive aspects of the grass-legume association. Adv. Agron. 33, 227-261.

6) Harris, W. 1985. Population dynamics and competition. In "White Clover" ed. by M.J. Baker and W.M. Williams, C.A.B. International, Aberstwyth, pp. 203-297.

7) Ito, M. 1988. Fundamental studies on weed management in fruit trees. Weed Res., Japan 33(2), 82-88. (in Japanese)

8) Kawanabe, S., K. Yoshihara, T.Okada, M. Ueno and M. Hidaka 1967. Studies on summer depression of pasture crops. 4. Influence of daylength upon the vegetative growth of white clover. J. Jap. Grassl. Sci. 13, 112-121. (in Japanese with English summary)

9) Nemoto, M. 1979. Ecological characteristics of important weed species in sown meadows. The response of tall-growing weeds to cutting. Weed Res., Japan 24(1), 12-18. (in Japanese with English summary)

10) Nemoto, M., M. Numata and M. Kanda 1977. The role of weeds in sown meadows in Japan. Proc. 6th. Conf. APWSS, 614-622.

11) Ochi, M. 1966. Study of regeneration of Ladino clover. 1. Regeneration of Ladino 
clover according to fertilizer application amounts and cutting seasons. Proc. Crop Sci. Soc. Japan 35, 71-77. (in Japanese with English summary)

12) Ochi, M. and T. Muroga 1967. Study of regeneration of Ladino clover. 2. Regeneration of Ladino clover according to cutting intervals and its seasonal variation. Proc. Crop Sci. Soc. Japan 36, 145-150. (in Japanese with English summary)

13) Sugawara, S. 1971. Studies on the shifts in weed vegetation in the maturation process of farms. Kyoto Univ. Ph. D. thesis. (in Japanese with English summary)

14) Takebayashi, T. 1985. Observation on the population shift of weeds in citrus orchard.
Weed Res., Japan 30(3), 237-244. (in Japanese)

15) Turkington, R. and J.L. Harper 1979. The growth, distribution and neighbour relationship of Trifolium repens in a permanent pasture 1 , Ordination, pattern and contact. J. Ecol. 67, 201-218.

16) Ward, C.Y., J.N. Jones, J.H. Lillard, J.E. Moody, R.H. Brown and R.E. Blaser 1966. Effects of irrigation and cutting management on yield and botanical composition of selected legume-ryegrass mixtures. Agron. J. 58, 181184.

17) Whittaker, R.H. 1965. Dominance and diversity in land plant communities. Science 147, 250-260.

\section{雑草制御を目的としたシロクローバ植被の維持 管理に及ほす刈取体系の影霎}

浅井元朗*・伊藤操子*・草薙得一*

\section{摘 要}

植被を利用した害草制御は樹園地など粗放的な 植生管理が求められる場面で有用であり, シロク ローバ (Trifolium repens L.) はその有望な材料と 考えられる。本研究はクローバ定着後の刚取体系が クローバの生育と植生動態に及ほす影響を調査し, 望ましい刚取体系について検討した。実験は大阪府 高梘市で行い, シロクローバ 2 品種 (コモン型：グ ラスランドフィア, ラジノ型: カリフォルニアラジ ノ)を 1991 年秋期に播種した。その後 2 年間, 春期 (4月中旬または 5 月初旬), 6 月, 8 月, 10 月の 4 時 期の組合わせによる 16 種の刚取体系（Table 1) を 実施し,クローバと雑草の植生調查を継続した。

1 年目（1992 年）の刚取はクローバ生育に与える 影響が少なく, 次の刚取までにクローバは再生し た。しかし 2 年目 (1993 年) の刚取によってクロー バ被度ならびにその植生は大きく変化した。6 月, 10 月の刚取は影響が大きく, 春期, 8 月の刚取は影響 が少なかった (Table 2)。特に 1993 年 6 月の刚取後

\footnotetext{
*京都大学農学部雑草学研究室
}

に大型のイネ科夏雑草 (アキノエノコログサ,メヒ シバなど）が繁茂し, クローバ被度は著しく減少し た (Fig. 1, Fig. 3)。6 月無刈取区では刈取区に比べ て夏期のクローバ被度の低下は小さく, 冬期の被度 は刈取区より高かった (Fig. 1, Fig. 3)。夏期に雑草 を除去した場合もクローバ被度の低下は小さかっ た (Fig. 2)。しかし, 刈取の有無にかかわらず, ク ローバの生育は前年より衰退した。

クローバ品種間ではラジノ型がコモン型に比べ て高い被度を維持し (Fig. 1), その雑草抑制効果も 優れていた (Fig. 3)。刈取ならびにその後のクロー バ被度の低下により生じた裸地には雑草が侵入し た。6 月の刚取後に夏雑草の発生が増加し，8，10月 の刚取後に冬雑草の発生が増加した (Table 3)。冬 雑草がクローバに与える影響は少なかったが, イネ 科夏雑草の庇陰によってクローバは著しく衰退し た。多年生のアレチギシギシ，ネズミムギは刚取に かかわらず増加した。

以上の結果から, 本地方ではラジノ型がその雑草 制圧力, 被覆の持続性において被覆資材として適す ること, その優占植生を維持するための管理法とし てはスプリングフラッシュ期以外の刚取を避ける べきであることが示唆された。

キーワード : シロクローバ, 草生被覆, 植生動態, 刈 取体系, 雑草制御 